Journal of Social and Development Sciences

Vol. 4, No. 10, pp. 449-460, Oct 2013 (ISSN 2221-1152)

\title{
The Failure of the 1917 Geddes Master Plan and 1959 Minoprio, Spencely, Macfarlane Master Plans: Some Reflections
}

\author{
*Bayezid Ismail Choudhury, Paul Jones, Peter Armstrong \\ Faculty of Architecture and Planning, University of Sydney, Australia \\ *bcho0140@usyd.edu.au
}

\begin{abstract}
Urban planning is inherently a political process addressing social justice and social coherence concerns. However, planners are fixated with the physical and superficial social aspects of planning, overlooking its deeper interrelationships. This paper discusses two master plans for the city of Dhaka. The first is the 1917 plan by Patrick Geddes, and the second is the 1959 Minoprio, Spencely and Mcfarlane Plan. Both plans were developed after a phase of social upheaval and unrest orchestrated to suppress the desires and wishes of the people of Dhaka. In both instances, the cross cultural planners lack cultural awareness, failing to perceive the then current issues fronting Dhaka. In essence, they work in isolation as planners. These initiatives can be argued as representing 'planning for planning's sake'. In this setting, this paper articulates that the failure of the two master plans were due to a lack of awareness of the social and political realities by these 'foreign' planners.
\end{abstract}

Keywords: Geddes Plan, 1959 Master plan, Dhaka, Colonial Planning, Essence of Planning

\section{Introduction}

Dhaka, the capital of Bangladesh once regarded as the Venice of the East, has been one of the most significant cities in the subcontinent since the Mughal rule. Once a Mughal capital, it declined in prominence when the colonial British government moved the capital elsewhere in 1715. However, it was valued for its strategic location by the Buriganga River and the British relocated the provincial capital to Dhaka 1 in 1905.This decision was overturned in 1911. Dhaka again regained its significance as the capital of East Pakistan, with the emergence of Pakistan as an independent nation in 1947. East Pakistan became Bangladesh and Dhaka its capital in 1971 (Chowdhury, Faruqui, 2009). According to Akhtar, "The selection of capital [Dhaka], whether central or provincial has always been influenced by certain geographical, political and economic considerations. The central or secure position of a place, its proximity to a river and the affiliation of the people whether a tribe, clan or political homogeneity are vital for the selection of a capital" (2009, p. 209). Several master plans have been developed for Dhaka, since the beginning of the twentieth century. The first was proposed by Patrick Geddes in 1917, during British Colonial rule. The partition of Bengal in 1905 and Dhaka's promotion to capital of the Eastern province ushered in a new era for the people of Bengal, particularly for Muslims. Partition was a significant factor in the major social, political, cultural and infrastructure developments of Dhaka at this time (Chakraborti, 2009). But due to the annulment of partition in 1911 Dhaka lost its prominent position. It was against such a backdrop, in 1916, that Geddes formulated his master plan after a short visit to Dhaka. Geddes had been invited by the Governor of Madras, Lord Pentland, to design several cities in India (Hayder, 1987). ${ }^{1}$

Geddes' report comprises nine chapters in a brief 22 page document. He underscored the need for comprehensive town planning. Inspired by the beauty of Dhaka, his vision is mostly rhetorical and utopian, firmly planted in the western tradition. Although the geography of Dhaka and other social aspects were defining factors of his plan, he failed to inspire a vision that could be formally implemented. Hayder (1987, p. 12) argues, "His proposal was an informal document - a sketchy guideline for the future development of the city. It never met with formal recognition". He argues that the main drawback of this plan was its

\footnotetext{
${ }^{1}$ Geddes studied natural science in London and Paris. He started his career at the University of Edinburgh in 1880 as a part time lecturer in natural science at the School of Medicine. Later he became Professor of Botany at Dundee College. He was engaged in town planning activities during this time (Meller, 1990)
} 
incompleteness and lack of details (Hayder, 1987). The second master plan for Dhaka was formulated in19592 by British planners, Minoprio, Spencely and MacFarlane, in a British post-colonial setting, under the Pakistani colonization of Dhaka. When Pakistan was carved out from India in 1947 it emerged as a country with its own unique problems (Choudhury, Bell, 2011; Mascarenhas, 1971). East and West Pakistan were not only separated by religion but were dissimilar in every aspect of life, such as food, clothing, customs, rituals and so on (Schuman, 1972). Unrest erupted in 1952 with the Vasha Andolon (language movement), which was the forerunner to subsequent political movement against West Pakistan. It was against this backdrop of political unrest that the 1959 master plan was formulated. The report consists of 15 chapters including, transport, public buildings, population, housing, education, open spaces, commerce, industry, public utility services, land for special purposes, and a proposal for Narayanganj (a city near Dhaka), planning administration and implementation, and legislation.

Over time the master plan failed to have any impact on urban Dhaka. Misdiagnosis of the projected growth of Dhaka led to its suspension (SENES, 2007; EPC, DE, 2010). According to the Dhaka Metropolitan Development Plan (DMDB)), " "However, the rate of growth of population of the city surpassed the plan targets by almost three times even during the planning period i.e., in 1981 the population of Dhaka was 3 million. So by the time the thinking for a new master plan was initiated in the early nineties, the earlier Master Plan [1959 Plan] had long become irrelevant" (SENES, 2007, p. 3-2). The purpose of the 1959 Master Plan was to provide a comprehensive plan for the anticipated rapid population growth of Dhaka ${ }^{4}$. As Dhaka was the capital of East Pakistan, the report sought to provide due importance to its physical, social, economic and cultural aspects. The report articulated some assumptions as guidelines for the Master plan including its importance in national policy. The report suggested that the Dhaka Improvement Trust would be the planning authority, which would function with the help of other government authorities. The main objective of the master plan was to establish planning principles including detailed planning principles (McFarlane et el, 1959). On the other hand, Geddes was commissioned in the backdrop of the annulment of the partition of Bengal. After annulment of the partition, Muslim leaders earnestly pleaded for cancellation of order and wanted to restore Dhaka as the capital of East Bengal. The British government decided to appease the Muslims by proposing the establishment of the University of Dhaka and (Islam, 2009) and the preparation of a Master plan for Dhaka (Choudhury et al, 2012, Biswas, 1995). This paper argues, however, that it was due to neither incompleteness nor lack of detail in the case of the Geddes plan, nor misdiagnosis of the physical growth of Dhaka, that these plans did not materialise. Rather it was due to lack of political insights and a failure to address prevailing social injustice. This argument is based on the premise that political vision and awareness and understanding are major factors in the success of urban planning. Hoch (1994, p. 361) asserts, "Planners may engage in the politics of vision, interests, and advocacy and do well. Planning thrives, however, in the political domain of deliberation and consensus". This paper considers Hoch's perspective in examining the contributing factors in the failures of the two Dhaka master plans.

\section{The Essence of Successful Planning: Understanding the Dynamic of Politics and Addressing Social Injustice}

Planning is a broad issue encompassing social, political, cultural, physical and environmental aspects, often viewed within the limits of physical terrain. Physical issues like land use, land allocation, and development control planning dominate the realm of urban planning. However, the essence of planning is rooted in its political dynamics and its democratic potential. Too often, the political context, involving interaction of

2 The firm was instructed to formulate a plan on $26^{\text {th }}$ August 1957 by the Secretary for Commonwealth Relations for the Dhaka Improvement Trust under the Technical Co-Operation scheme of the Colombo Plan. It took a year to prepare the working plan (MacFarlane et al., 1959).

3 The Dhaka Metropolitan Development Plan (DMDP) is comprised of three levels of planning, the Structure Plan, the Urban Area Plan and the Detailed Area Plan (DAP). The Dhaka Structure Plan (1995-2015) and the Urban Area Plan (1995-2005) were endorsed and published in the Bangladesh Gazette between1992-1995. The DAP has also been prepared following the policies and guidelines set out in the Structure Plan and Urban Area Plan (DMDB).

${ }^{4}$ The population factor for Dakha at this time was 57,500 per 220 square miles (MacFarlane et al., 1959) 
people in a city is ignored. Cherry (1970, pp. 61-2) points out, "up until now planning has been obsessed with the idea of place: instead, it is argued that the essence of the city and city life is interaction". Planning is a process requiring a deep and thorough understanding of underlying socio-political issues and trends (Cherry, 1970). Thus politics emerges as an inseparable part of planning as it pertains to its social context. The domain of planning has been politicised more so than most other professions (Dimitriou, 1973). As such the dynamics of politics in urban planning is a reality (Greer, 1964). The ultimate outcome of planning, which revolves around the distribution of wealth and power, is determined by the act of politics. As Beckman (1970, p. 114) states, "Planning helps to determine 'who gets what, when and how', and to do that is to function politically". This dominance of politics in urban planning also emerged from the discourse set out by many scholars, such as Vasu (1979), Post (1996) and Friedmann (2005). The pervasive role of politics in planning makes it necessary for planners to address this issue in a more sensitive way. Thus the role of planners in democratic planning should transcend the usual role of physical planner to mediator, negotiating and resolving issues between aggrieved parties associated with ethno-cultural difference (Burayidi, 2000). This paper argues that the failure of the two master plans was mainly due to the apolitical role of both planners. The desired role of planner as politically articulated individual (Krumholz, 1995) can be best understood from Catanese's (1984, p. 23) statement, "planners must deal more adequately with the realities of politics and its inevitable need for compromise, consensus, and coalition".

This paper argues that both the 1917 Geddes plan and the 1959 plan disregarded the democratic essence of planning, eventually rendering both plans non-functional. According to Rydin (2011, p. 10), "So planning becomes a public space in which democracy is defined in practice. It identifies which voices a society regards as having a right to be heard and, beyond that, to have significant influence". In Rydin's view, the core of planning is democracy (2011). Burayidi (2000) reinforces this view of planning as a process of social justice, arguing that planning is inherently a democratic process through which marginalised peoples, with the help of the planner, address their felt need and aspiration. The role of advocacy planning, which has political underpinnings in realizing democratic planning, is acknowledged in contemporary planning ${ }^{5}$ (Ross, 1974). Ross' arguments that advocacy planning must be based on an understanding of political dynamics support our hypothesis in relation to the failure of the two master plans. Ross (1974, p. 226) argues, "Advocacy planning where the planner comes from 'outside', 'gives' his contribution and then gets out is not enough. Advocacy planning must be political, that is, it must be a part of the political struggle". The underlying themes of advocacy and democratic and comprehensive planning are aimed at addressing social injustices with sensitivity, mainly in regard to class, race, sex and culture (Burayidi, 2000). Davidoff asserts in this context, "comprehensive planning in a democratic society would seek to redress the fundamental injustice of the society: inequality, prejudice, galling poverty" (1967, p. 159). Thus comprehensive and democratic planning seeks to resolve issues mainly resulting from a "clash of interest", evolving from cultural and political differences (Burayidi, 2000). In this way, Burayidi asserts, planning can become one means for righting past injustice. Central to the argument of this paper, is the absence of a mediating role by the master planners of 1917 and 1959 in resolving conflict.

The Politics of Colonial Planning: As both the master plans discussed in this paper were devised in a colonial setting, under British and Pakistani colonial rule, it is useful to shed some light on the underlying political issues in play under colonial rule in general. Findley (2005) states that the discipline of architecture and planning mainly fulfils the desire and whim of those in power. Great architecture and spatial plans can be regarded as vehicles for demonstrating power. Moreover, Findley states colonialism cast its far-flung influence through the introduction of spatial and architectural practice to the colonies. Similarly, Njoh (2007) writes that urban planning and policy was a vehicle to impose a British Colonial attitude, to instil the idea of civilising the "inferior race" or a "mission civilisatrice". The 1917 Geddes plan is inherently a controlling device by the British. After partition in 1947, little changed in planning terms. The Pakistani approach and attitude to urban planning was like that of a colonial ruler. Gable (1967, p. 478) discusses the Pakistani policy, "with the departure of the British, those trained by the British constitute the group with the continuity to project British values -'an elite within an elite'". Thus, from the bureaucratic perspective, the1959 master plan is also fraught with flaws in terms of intention, apart from its apolitical approach. Colonial planning and

${ }^{5}$ The idea of advocacy planning is similar to that of the role of the lawyer in helping a client (Ross, 1974). 
other policies were introduced mainly to govern the interests of the coloniser: "the colonial rule engaged in various practices for their own survival and fulfilment, which simultaneously resulted in movements that eventually undermined the whole system" (Gable, 1967, p. 475).

\section{The Dynamic of Politics and Social Injustice — the 1917 Geddes Plan}

The immediate history of politics and social injustice prior to the 1917 Geddes master plan has its roots in the $11^{\text {th }}$ century. From that time a complex ethnic and religious situation characterised the life of the city of Dhaka and the rest of Bengal. The harmonious life of the people of Dhaka during the Pala rule (from the $8^{\text {th }}$ century) was seriously disrupted by the Sena Dynasty, which took over Bengal and Dhaka at the end of the 11th century. The Brahmin rulers of Sena introduced the caste system (Dasgupta, 2004), generating widespread dissatisfaction and anger within the lower castes (Dasgupta, 2004; Choudhury, Armstrong, 2012). The Sena were dethroned by the Muslims, originating from the Middle East (Turkey, and Afghanistan) in the $13^{\text {th }}$ century (Choudhury, Armstrong, 2012 Schendel, 2009). The philosophy of Islam propagated by these foreign missionaries radically changed the lifestyle of the lower castes after mass conversion to Islam. This conversion gave them a sense of emancipation from the Hindu Brahmins ${ }^{6}$ (Uddin, 2006; Khan, 1985).This Islamic identity was a strong feature of the $r$ subsequent cultural and political development of Dhakaites (Khan, 1985), particularly the emergence of Muslim nationalism during the period of British intervention in this region (when the British took over from Mughal and Nawabi rule after the battle of Plassey in 1757). ${ }^{7}$ The Hindus became close allied with the British and thus Muslims of this region were marginalized (Ashraf, 1982). With few exceptions, the Muslim people of Dhaka remained apart from all kind of social, political and cultural development until the early $20^{\text {th }}$ century. Khan $(1985, p .842)$ illustrates the Hindu domination of the administration of Bengal and Dhaka,

Because the comparatively early establishment of British rule in Bengal, and because Hindus took to British ways far more willingly than Muslims in these early years, overwhelmingly Hindu elite directed the socioeconomic, political, and administrative affairs for the majority of Bengali Muslims at the turn of the twentieth century. Muslims were disadvantaged in all aspects of life compared to Hindus. According to Ray (1977, p. 43), "In Bengal, in 1901, only 22 out of every 10,000 Muslims knew English compared to 114 out of 10,000 Hindus. They held only 41 of the 'high appointments' under the government while the Hindus, who were less than twice as numerous as the Muslim, held 1,235"8. The Hindu dominated administration was mainly

${ }^{6}$ The first chronicle of Hindu Muslim conflict was in the $13^{\text {th }}$ century in Bengal and other parts of India. This long standing conflict and mistrust continued in India and Bengal till the creation of the Muslim state of Pakistan (East and West) in 1947 based on 'Two Nation Theory'. Jinnah, the father of Pakistani nationalism propagated the idea of two nation theory in all India Muslim league Conference in 1940. Jinnah declared "The Hindus and Muslims belong to two different religious philosophies, social customs and literatures. They neither intermarry, nor dine together, and they belong to two different civilizations which are based mainly on conflicting ideas and conceptions" (Jamil-ud-din Ahmed, Historic Documents of the Muslim Freedom (Lahore, 1970, p. 380).The grievances of Bengali Muslims culminated due to dominance of Hindu landlords over the Muslim peasantry in the first half of the 19th century. The eruption of Ferazee and Wahabi movement by the Muslims was a reaction to the tyranny of Hindu landlords in Bengal (Chattopadhay, 1977). 7 The Mughal (Muslims from Central Asia) emerged as one of the supreme powers in the history of Northern India when Babar, the first Mughal ruler, defeated Ibrahim Lodi in 1526 (Baxter, 1997).The Mughal took over Bengal and Dhaka in 1610 and renamed Dhaka as Jahangirnagar after the Mughal ruler Jahangir. Dhaka was made provincial capital at that time (Schendel, 2009). Later in 1715 the capital was shifted to Murshidabad, leading to the decline in the importance of Dhaka (Baxter, 1997). The Battle of Polashi in 1757 marked the end of Mughal rule in Bengal with the defeat of Nawab Siraj-udidoula. Following this battle the British ruled in Bengal (Schendel, 2009).

${ }^{8}$ Following table shows increasing number of Muslims at the turn of $20^{\text {th }}$ century in undivided Bengal. 
governed from Calcutta, which was the capital of India till 1912 and the major administrative and cultural centre in the early $20^{\text {th }}$ century (Khan, 1985). Despite a much greater contribution to the national economy, Dhaka and eastern Bengal remained under-developed..$^{9}$ The people of Dhaka, especially Muslims, were well aware of their deprived status and desperately sought the attention of the British, shifting from their previous anti-British stand. Their concern was addressed before the Hunter Commission of 1882-1883 and the Aitchison Commission of 1886-87. Their worries were mostly concentrated on the changes to the rules of entrance to the Indian Civil Service (Dhar, 1987). Some of those in the British elite understood the situation and were sympathetic to the plight of the Muslims (Dhar, 1987). Dhar states, “The British government also responded to the feeling of the Muslims and gave some facilities to the Muslim students to make English education available at lower fee. As a result the well to do Muslims could come closer to the British and availed themselves of English of the English education" (Dhar, 1987, p. 39). The English education of Muslims contributed significantly to their close ties to the British and to the formation of political parties to fight for their cause. In February 1904 Curzon visited eastern Bengal. He understood Muslim grievances and the distress and neglected administrative and educational structure of Eastern Bengal and Dhaka. ${ }^{10}$ According to Ray (1977, p. 34), "all this could happen, because 'the old government was engrossed' with Calcutta and the surrounding areas where they were spending practically the whole revenues of Bengal". Lord Curzon responded by creating a new province of eastern Bengal and Assam by dividing the greater Bengal (Ray, 1977). On 16 ${ }^{\text {th }}$ October 1905, the partition of Bengal came into effect. Dhaka became the capital of Eastern Bengal and Assam (Akhtar, 2009). Despite Hindu dissatisfaction and the majority of the British supporting the Hindus the partition went ahead because of Curzon's unyielding support for the Muslims (Ray, 1977). ${ }^{11}$

\begin{tabular}{llll}
\hline Table 1 & & & \\
\hline Census year & Hindus & Muslims & Tribals \\
1981 & & & \\
1891 & $1,80,71,296$ & $1,83,71,296$ & $3,13,089$ \\
1901 & $1,89,78,300$ & $2,01,74,832$ & $4,64,820$ \\
1911 & $2,01,55,674$ & $2,19,54,955$ & $7,30,594$ \\
1921 & $2,09,48,357$ & $2,42,37,228$ & $8,49,045$ \\
1931 & $2,08,12,529$ & $2,54,86,124$ & $19,25,457$ \\
\hline
\end{tabular}

Source : Chatterjee, S. P. (1947, p. 2). The Partition of Bengal: A Geographical Study. Calcutta, Geographical Society.

\section{Proportion of the three communities in Bengal}

\begin{tabular}{lccc}
\hline Census year & Hindus & Muslims & Tribals \\
1881 & 4,882 & 4,969 & 149 \\
1891 & 4,767 & 5,068 & 165 \\
1901 & 4,700 & 5,119 & 181 \\
1911 & 4,523 & 5,234 & 243 \\
1921 & 4,372 & 5,255 & 273 \\
1931 & 4,348 & 5,444 & 208 \\
1941 & 4,198 & 5,430 & 372 \\
\hline Source: Chatterjee, S. P. (1947, p. 2). The Partition of Bengal: A Geographical Study. Calcutta, Geographical Society.
\end{tabular}

${ }^{9}$ Dhaka and adjacent area of east Bengal became important economically in the 1850s due to the Crimean war, as most of the jute supplied came from this part of India. This jute boom contributed significantly to the national economy of India (Akhtar, 2009).

10 There are several theories in relation to this partition. Ray asserts, "The British did this partition to facilitate administrative convenience. British administration assumed the area of 189,000 square mile and with a population of seventy-eight million was too large to be administered effectively" (Ray, 1977). Dhar, on the other hand asserts, "It was a predetermined machination from the part of British to divide and rule the Muslim and Hindu community and thus break undercurrent harmony of a nation" (1987). It is, however, fact that the relationship between Hindus and Muslims became seriously strained due to the partition (Ray, 1977).

11 The act of Partition by Curzon did not please most of the Hindus and he appeared to them as a reactionary dictator with lack of vision (Ray, 1977). However, Biswas, a Hindu academic asserts, the act of division by 
The partition of Bengal ushered in a new era in the life of Dhaka with a promise and hope of renewed development in all sectors, especially education, administration and architecture (Chakraborti, 2009; Islam, 2009).12 Chakraborti, (2009, p. 252) writes, "As the capital of the Eastern Bengal and Assam, Dhaka regained its dignity and many of the government offices with all their paraphernalia were established in the city". The partition of Bengal and with Dhaka as capital also opened horizons for the politically conscious Dhakaites. Thus the 'All India Muslim League' was born at Dhaka in 1906 (Islam, 2009; Schendel, 2009). Islam (2009, p. 223) writes, "The birth of the Muslim league undoubtedly strengthened the solidarity of the Muslims on the one hand, while on the other, the relationship between (Hindu and Muslims) became strained". The partition was also instrumental in the introduction of representative politics in urban municipalities including Dhaka, later expanded to other areas (Schendel, 2009). Thus the fruits of partition transcend the boundary of Dhaka. The Hindus of Calcutta feared the loss of power and economic control due to the development of Dhaka's administrative reform and infrastructure and agitated against partition. In particular, lawyers in Calcutta were concerned at changes in the High Court in Dhaka (Ray, 1977; Schendel, 2009). As part of their opposition to partition, the Hindus boycotted British goods, creating a movement known as the Swadeshi Movement. According to Ray (1977, p. 40), "Surrendranath and Gokhle [constitutional politicians] looked upon the boycott as an economic weapon to be used temporarily against the British government until the injustice was undone, that is, the partition was revoked"..

Finally in the face of Hindu resistance the Prince of Wales King George annulled the partition of Bengal on 12 December, 1911 at the Durbar of King George V (Cronin, 1977). To many Muslims the politics of the British and Hindus had combined to deprive the Muslims and Dhakaites from their fair share (Khan, 1985).13 With the annulment of partition Dhaka was no longer a capital city and development ceased. Chakravarti (2009, p. 252), a Hindu scholar argued, "The annulment of the partition of Bengal virtually reduced the status of Dhaka almost to that of the earlier time". It was against such a backdrop that Geddes devised his plan for the development of Dhaka. But it did not consider the political context and was not sympathetic to the social injustice of the annulment of partition. Further shocking to Dhakaites, the report was published in Calcutta by the Bengal Secretariat Book Depot (Geddes, 1917). All those Gedddes acknowledged in the report were Hindus, further demonstrating a disregard of the Muslim majority in Dhaka.

\section{The Dynamic of Politics and Social Injustice - the 1959 Minoprio, Spencely, MacFarlane Master Plan}

The story of politics and social injustice in 1959 is similar in style to that of 1917. When the British departed India in 1947 they divided India into two parts based on religion. The area where Muslim concentration was high became Pakistan (Schendel, 2009). Pakistan was divided into West and East, situated $1500 \mathrm{~km}$ apart (Schendel, 2009). East Pakistan was mainly a Riverina province with fertile land, mostly inhabited by Muslims. West Pakistan is a comparatively arid and dry area populated by descendents of Aryans. The East had the larger proportion of the population. Of 78 million people in Pakistan in 1951, 44 million (55\%) lived in East Pakistan. Dhaka was regarded as the second capital of Pakistan (Schendel, 2009). Partition

Curzon was a prudent one to address the grievances of the majority of deprived Muslims in Bengal and Dhaka.

12 Governor's Residence and Curzon Hall are two architectural examples from this period (Schendel, 2009).

${ }^{13}$ Muslim leaders in Dhaka continued their political activities to stop the annulment decision but failed. They were in part appeased when finally Lord Harding, the viceroy of British India in his sojourn in Dhaka recommended the secretary of state to India to establish the University of Dhaka (Islam, 2009). On 2 February 1912, the government of India decided in principal to establish the University of Dhaka and formed a commission named 'Calcutta University Commission' to look after the matter (Islam, 2009).Thus the Hindu governed commission assumed authority and interfered in this decision. They ensured as much delay as possible to establish the University of Dhaka (Biswas, 1995). Geddes' plan included much discussion about the University. 
perpetuated the social injustice of Dhaka under British colonial rule. Although Pakistan was independent, $\mathrm{f}$ or most East Pakistanis and Dhaka based politically conscious elite, it was not the emancipation they sought (Baxter, 1998, p. 61). As Baxter states, "but to the majority of East Pakistanis this would not prove to be the independence they desired". East and West were separated in all aspects of life apart from religion. West Pakistan was a heterogeneous state with five major languages and diverse dialects and caste system. East Pakistan was mostly linguistically and culturally homogeneous (Islam, 1981). Religion was the only common factor but not enough to tie them together. East Pakistanis were dissatisfied due to several factors, including language, disparity in economic development, infrastructure and education, uneven administrative structure and participation in the military and constitutional issues (Jahan, 1972; Baxter, 1998; Maron, 1955).

The first manifestation of this dissatisfaction emerged in the language movement in 1952, and its uprising in the streets of Dhaka.This language issue generated two separate episodes of resistance - one in 1948 and another in 1952. The latter resistance 'Bhasha Andolon' was marked by the death of five language martyrs (Thompson, 2007). When Jinnah ${ }^{14}$ visited East Pakistan in September 1948, he declared, "Let me make it very clear to you that the state language of Pakistan is going to be Urdu and no other language" (Lewis, 2011, p. 63). The people of Dhaka and East Bengal rejected this declaration. In 1952 in a meeting in Dhaka, Prime Minister Nizamuddin, a Bengali, declared that Urdu was to be the only state language of Pakistan (Lewis, 2011). This declaration sparked a movement in the streets of Dhaka. An attempt was made to suppress the movement by the provincial government, leading to the death of five students during a protest march (Islam, 1981).This language movement was the forerunner of a subsequent movement that led to the war of independence in 1971 (Thompson, 2007). ${ }^{15}$ As a consequence of these protests, the Pakistani authorities agreed to accept Bangla as one of the state languages and the 1956 constitution recognised both Urdu and Bangla as the state language of Pakistan (Thompson, 2007). ${ }^{16}$ Despite the formal recognition of Bangla in 1956 attempts by the government to 'Islamicise' the language to align it with Urdu continued (Islam, 1981), contributing to ongoing conflict between Muslims of East and West Pakistan (Islam, 1981). The bitterness of this relationship was evident in the 1954 provincial election in which the Muslim League, a party mainly based in West Pakistan, was defeated, ${ }^{17}$ with the United Front Party, a Bengali nationalist party based in Dhaka opposed to Muslim nationalism, emerging victorious. ${ }^{18}$ A new era of Bengali government was born (Islam, 1981). According to Maron "Fazlul Haque, a veteran Bengali politician, organised the new government and immediately begun to demand freedom from the domination and exploitation by Karachi" (1955, p. 134). Haque's assumption of power as chief minister brought new hope to the Bengali people (Schendel, 2009). Schendel (p. 117) asserts, "This mid 50 was a brief period of Bengali renaissance against colonial occupation. The elections of 1954, however gave them renewed hope of a real partnership. This hope was soon tempered, however, when the new government was summarily (and undemocratically) dismissed, initiating a four year period of political confusion and instability".

\footnotetext{
${ }^{14}$ Jinnah was regarded as the Father of Pakistan and the Founding President of the Pakistan Muslim League (Khan, 1985)

${ }^{15}$ According to Bhattachargee (1973) and Islam (1981) the language movement by University students, professors, journalists, writers and artists ignited a spark in the Bengali culture that led to subsequent movement (Bhattachargee, 1973, Islam, 1981). The spirited nationalist Bangla slogan of "Jai Bangla" that inspired people of Bangladesh during the war of independence emerged from the other slogan 'Rashtra Bhasha Bangle Chai' during the language movement in 1952 (Bhattachargee, 1973; Islam,1981).

${ }^{16}$ Just- because at that time there were dozens of languages in all over the Pakistan and 'Urdu' was spoken by only $3 \%$ of all Pakistanis. Bangla on the other hand was spoken by $56 \%$ of overall population of Pakistan (Schendel, 2009).

${ }^{17}$ All India Muslim League was founded in Dhaka in 1906 .Muslim league is a party constituted by Muslims in response to Hindu dominated congress in India. Muslim league was instrumental in creation of Pakistan. Jinnah from West Pakistan was president of this party (Qureshi, 1972-73). The people of Bengal was the fervent supporter of the Muslim League in the struggle of independence of Pakistan (Maron,1955)

${ }^{18}$ The United front party was a coalition of many small and large parties. Awame League was one of the largest party of united front bagging $46 \%$ of the seats. The United front manifesto revolved around 21 points. Four of such addressed recurring language issue, and the rest of it addressed issues like autonomy, people's right and economic emancipation (Schendel, 2009).
} 
This perceived injustice had far reaching effects for the people of Dhaka. One such impact was economic disparity. The economic gap between East and West Pakistan, existing since independence, increased substantially by 1958 (Jahan, 1972). Per capita income rose from Rs.330 in 1949-50 to Rs 373 in 1959-60 in West Pakistan, but declined from Rs 373 to Rs 288 in East Pakistan (Jahan, 1972). The following figure (Table 2) shows the economic disparities between East and West Pakistan, for the period 1947-1955 (Lambert, 1959, p. 53). There was also disparity in terms of education and infrastructure. While enrolment of primary school students rose 163\% in West Pakistan, in the East it rose only 38\% in the 1947-58 periods. Enrolment in secondary schools rose to $64 \%$ in the West but only $6.6 \%$ in the East. University enrolment increased by $38 \%$ in West Pakistan and by $11.2 \%$ in East Pakistan over the same period. Jahan (1972) compares transport and infrastructure during this period, with Dhaka and East Pakistan generally behind in the physical aspects of urban planning. In terms of administration and representation of in the defence service, East Pakistan was also behind, as shown in the following (Table 3).

Table 2

\begin{tabular}{lll}
\hline West Pakistan Rs (millions) & & East Pakistan (millions) \\
\hline & & \\
Financial assistance & 10,000 & 1,260 \\
Capital expenditure & 2,100 & 620 \\
Grants-in- aid & 540 & 180 \\
Educational grants & 1,530 & 240 \\
Foreign aid allocated & 730 & 150 \\
Defence expenditure & 4,650 & 100 \\
Foreign trade (exports) & 4,830 & 4,940 \\
\hline
\end{tabular}

Table 3

From West Pakistan from East Pakistan

Secretaries (central)

Joint secretaries

Deputy Secretaries

Under secretaries

(Lambert, 1959, p.53)
19

38

123

510
0

3

10

38

\begin{tabular}{llc}
\hline & From West Pakistan & from East Pakistan \\
\hline Lt. Generals & 3 & \\
Major Generals & 20 & 0 \\
Brigadiers & 34 & 0 \\
Colonels & 49 & 1 \\
Lt. Colonels & 198 & 1 \\
Majors & 590 & 2 \\
Air Force Personnel & 640 & 10 \\
Naval Officer & 593 & 60 \\
\hline
\end{tabular}

(Lambert, 1959, p 54)

Pakistan foreign policy in the decade prior to the 1959 master plan also favoured West Pakistan. As Maron (1955, p. 1443) pointed out, "Up until the SEATO pact, it could be said that the foreign policy of Pakistan was in fact the foreign policy of west Pakistan. The central government has displayed remarkable indifference to the feeling East Pakistan in these matters and here again has shown itself unrealistic". During the 1950s, the new national constitution of Pakistan was being created. As Baxter (1998, p. 69) points out, "The eventual formula adopted in the 1956 constitution provided for one house with equal membership from each wing, 
thus under representing the east wing". Against this setting of discrimination against East Pakistanis, in 1958, the Pakistan army took control of Pakistan, rejected the constitution and exercised martial rule. ${ }^{19}$ Ayub Khan, a Sandhurst trained military dictator, took control of Pakistan assuming the role of commander-in-chief of the armed forces (Schendel, 2009), with a significant negative impact on the people of East Pakistan as Schendel (2009, p. 118) states. Here military rule meant the power was now even more decisively in the hands of non locals. East Pakistan's elite had wielded power mainly through political mobilization, not through the army or the Bureaucracy.

The people of East Pakistan were further marginalised. "Bureaucracy and Army became the symbols of western domination over the East" (Islam, 1981, p. 61). It is against this political backdrop that the Dhaka Master Plan of 1959 was formulated by British firm Minoprio, Spencely and MacFarlane, drafted and organised under the supervision of the Dhaka improvement Trust. ${ }^{20}$ The Dhaka Improvement Trust was an inherently top-down bureaucratic institution used to regulate the growth of Dhaka. At that time almost all bureaucratic institutions were dominated by West Pakistan (Jahan, 1972). ${ }^{21}$ Hayder portrays the situation in regard to the bureaucratic pitfalls of the 1959 Master Plan, "Thus the future of the city eventually fell into the hands of tyrannical and whimsical decision makers" (1987, p. 98).

\section{Discussion and Results}

This paper has presented two stories of politics and social injustice in East Pakistan, both having a significant impact on the development and implementation of two major master plans for Dhaka, one in 1917 and the other in 1959. This paper argues that both planners formulated their respective master plans for the sake of planning alone and did not fully understand or comprehend the wider political, cultural and social context in which they were operating. The aspirations and identity of Dhakaites were subsumed in superficial concerns about land use. Jacobs (1995, p. 428) argues in relation to the inspirational aspects of planning, "the emphasis of city planning upon the physical nature of the city is perfectly reasonable, although no one would deny for a moment that the man-made physical environment should be responsive to people and to social and economic issues and aspirations". In regard to the relationship between planning and identity, Rabinovitz (1967, p. 19) asserts, "Thus planning has been aptly referred to as a function in search of an identity".

The true strength of planning lies in the identification of the root causes that hold back the development of society (Cherry, 1970). The two stories in this paper show that each plan was initiated when, in the case of the Geddes plan, Dhaka was elevated to the status of provincial capital, and in the case of the 1959 plan, when Dhakaites elected their own representatives to power in 1954. This suggests that political emancipation played a pivotal role in the aspiration of the people of Dhaka at these two pivotal periods in their history. But, unfortunately, in both instances, the hope that came with political emancipation was not fulfilled because of intervention by colonial and post-colonial ruling powers. The failure of Geddes and Minoprio, Spencely and MacFarlane to understand and explore the intricacies of the political, cultural and social context in which the plans were developed meant that neither plan could be implemented. Instead of providing ideas on land use and social planning the planners could have seized the opportunity to adopt a cross-cultural perspective, assuming the role of negotiator and mediator, thus enabling planning that encompasses advocacy and democracy and comprehensively addresses the needs of the people and society. As Hendler (1995) states, the role of planning is to resolve past wrong and uphold the right of deprived citizens. This view is supported

\footnotetext{
${ }^{19}$ This coup by Ayub Khan was endorsed by top bureaucrats and powerful business interests in order to withheld power from inept and corrupt politicians. Parliamentary democracy was brought to an end, the press was civil service were controlled by the (Schendel,2009)

20 The Building Construction Act of 1952 and the Town Improvement Act of 1953 allowed for the development of metropolitan Dhaka and the responsible parent organisation, the Dhaka Improvement Trust (Zaman, 2000).At present it is called Rajdhani Unnayan Kartipaksha.

${ }^{21}$ Lambert's statistics show the dominance of West Pakistani Bureaucrats prior to the 1959 Master Plan. However, a committee was formed after the 1962 constitution in relation to the function and the structure of the central government. The report of the committee suggested an increase in East Pakistani participation (Jahan,1972).Nonetheless, after the increase in number the situation remained the same as the control of power mainly rested with the central government (Jahan,1972).
} 
by Catanese (1984, p. 27), "The planners should learn the skills of the politician with regard to compromise, conflict resolution, negotiation, and arbitration. This is the only way for the planners to become a significant force for change".

Planning is about the future, and creating a vision (Rydin, 2011). According to Catanese (1984, p. 23), "Planners are inherently Long Range thinkers", with this long range vision incorporating political foresight. Dimitriou argues (1973, p. 64), "Ultimately, the activity of planning has its centre of gravity in the future where as politics must be concerned with the present" (1973, p. 64). Unfortunately, by failing to understand the context in which their plans would be implemented, both Geddes and Minoprio, Spencely and MacFarlane failed to impart any visionary political idea that could have generated renewed hope for the people of Dhaka. Instead they failed to question the autocratic administrations in power at the time, consequently developing master plans devoid of an awareness of the ethos and aspiration of the people. Both the plans focused on the physical aspect of land use and land zoning, without taking into account of the social struggle underpinning the success or otherwise of the plans. Both planners and their support organisations could have utilized the opportunity of a social mediator, by implementing a cross-cultural neutral perspective to resolve the crisis. As Hendler (1995) states, the central role of planners is to rework the social issues, that is, addressing the psychological and emotional needs of the people. This view is supported by Catanese (1984, p. 27), "The planners should learn the skills of the politician with regard to compromise, conflict resolution, negotiation, and arbitration. This is the only way for the planners to become a significant force for change".

In Retrospect: The significance of this paper lies in its attempt to highlight underlying politics as a key factor in democratic planning but also to project the idea that cross cultural planning requires a greater understanding of the socio-cultural and political underpinnings of society. Planners, particularly those from a different culture, must act with cultural sensitivity. Burayidi (2000, pp.2-3)_argues, "planners working in third world countries cautioned against the wholesale transfer of planning techniques and procedures from the west to the third world without modification to suit these countries unique conditions". In both instances the politically charged setting of Dhaka was ignored or misunderstood by foreign planners. ${ }^{22}$ This also raises questions about appropriate development in the developing world and the ethical aspects of cross cultural planning. In complex socio-political situations such as Dhaka, potential visionaries encounter serious dilemma and difficulty due to their lack of understanding of context. Hoch's view that "The visionaries, however encounter serious difficulties in politically charged setting:" (1994, p. 299) is also applicable to both plans and the expatriates who lead them. In summary, we may conclude that for planning to be successful it is imperative to consider the political milieu, the setting, the context. How can this political understanding be better incorporated into the role of the planner, without undermining the profession? As Post (1996) states, "As a result of the political strain, planning as an autonomous profession is increasingly discredited" (p. 125). Politics is a reality which plays a pivotal in role in realizing the perceived idea of planner.

\section{References}

Akhtar, S. (2009). On The Selection of Dhaka as the Capital of Eastern Bengal and Assam 1905-1911. In S. Ahmed (ed.) Dhaka: Past, Present and Future. Dhaka, Asiatic Society of Bangladesh.

Ashraf, M. (1982). Muslim Attitudes towards British Rule and Western Culture in India in the First Half of the Nineteenth Century. Delhi, India, Idarah-i Adabiyat-i Delli.

Baxter, C. (1997). Bangladesh: From a Nation to a State. Boulder, West views Press.

Beckman, N. (1970). The New BPBS: Planning, Politics, Bureaucracy and Salvation. T. L. B. a. G. Lathrop. New York, Odyssey Press.

Bhattachargee, G. P. (1973). Renaissance and Freedom Movement in Bangladesh. Calcutta, Mivera Associates.

Biswas, A. K. (1995). Paradox of Anti-Partition Agitation and Swadeshi Movement in Bengal (1905). Social Scientist, 23(4/6), 38-57.

Burayidi, M. A. (2000). Urban planning in a Multicultural Society. Westport, CT, London, Praeger.

Catanese, A. J. (1984). The Politics of Planning and Development. Beverly Hills, Sage Publications.

\footnotetext{
${ }^{22}$ The Master plan of Islamabad (Pakistan) by Greek Planner Doxiadis is another failed case of cross-cultural planning. The plan did not materialize due to an inadequate institutional framework to support the master plan (Maria, 2006).
} 
Chakraborti, R. (2009). Role of Dhaka after Annulment of Partition. Dhaka: Past Present Future. In S. Ahmed (Ed.), Dhaka: Past, Present and Future. Dhaka, Asiatic Society of Bangladesh.

Chatterjee, S. P. (1947). The Partition of Bengal: A Geographical Study. Calcutta, Geographical Society.

Chattopadhayay, D. K. (1977). The Ferazee and Wahabi Movements of Bengal. Social Scientist, 6(2), 42-51.

Cherry, C. E. (1970). Town Planning in its Social Context. London, Leonard Hill Books.

Choudhury, B. I. \& Armstrong, P. (2012). Monuments and Architecture Shaping Bangladeshi Identity. Global Built Environmental Review, 8(3), 45-67.

Choudhury, B. \& Bell, G. (2011). The Engagement of Khan and Kahn in Jatio Sangsad Bhaban. Architecture Plus Design, 28(4), 104-111.

Choudhury, B., Armstrong, P. \& Jones, P. (2012). Why Geddes Plan Didn't materialize: Planning for Planning Sake in the Case of Dhaka. $5^{\text {th }}$ International Urban Design Conference: Opportunistic Urban Design2012, Melbourne, Australia.

Chowdhury, A. \& Faruqui, S. (2009). Physical Growth of Dhaka City. In S. Ahmed (Ed.), Dhaka: Past, Present and Future. Dhaka, Asiatic Society of Bangladesh.

Cronin, R. P. (1977). British Policy and Administration in Bengal, 1905-1912: Partition and the New Province of Eastern Bengal and Assam. Calcutta, Firma KLM Private Ltd.

Dasgupta, A. (2004). Islam in Bengal: Formative Period. Social Scientist, 32(3/4), 30-41.

Dhar, P. N. (1987). Bengal Renaissance: A Study in Social Contradictions. Social Scientist, 15(1), 26-45.

Dimitriou, B. (1973). The Interpretation of Politics and Planning. Pergamon Press, 7, 55-65.

EPC, D. E. (2010). Preparation of Detailed Area Plan for Dhaka Metropolitan Development Planning (DMDB) Area, Dhaka.

Findley, L. (2005). Architecture, Politics and Cultural Agency. New York, Routledge.

Friedmann, J. (2005). Globalisation and the Emerging Culture of Planning. Progress in Planning, 64, 183-234.

Gable, R. W. (1967). Bureaucratic Transition: The Case of the British Colonies. Public Administration Review, 27(5), 474-482.

Geddes, P. (1917). Report On Town Planning, Dacca. Calcutta.

Greer-Scott, D. W. M. (1964). The Political Side of Urban Development and Redevelopment. Annals of the American Academy of Political and Social Science, 352, 62-73.

Hayder, Z. (1987). Organic Cities and the Case of Patrick Geddes in Dhaka. Architecture. Massachusetts, Massachusetts Institute of Technology. Master of Science.

Hendler, S. (1995). Planning Ethics. New Brunswick, New Jersey, Centre For Urban Policy Research.

Hoch, C. (1994). What Planners Do. Chicago, Illinois, Washington, Planners Press.

Islam, M. N. (2009). The Political Role of Dhaka. In S. Ahmed (Ed.) Dhaka: Past, Present and Future. Dhaka, Asiatic Society of Bangladesh.

Islam, N. (1981). Islam and National Identity: The Case of Pakistan and Bangladesh. International Journal of Middle East Studies, 13(1), 55-72.

Jacobs, A. B. (1995). Looking Back. In J.M. Stein (Ed.) Classic Reading in Urban Planning. New York, St. Louis, San Francisco, Aukland, Bogota, McGraw-Hill.

Jahan, R. (1972). Pakistan: Failure in National Integration. New York, Columbia University Press.

Khan, Z. R. (1985). Islam and Bengali Nationalism. Asian Survey, 25(8), 834-851.

Krumholz, N. J. F. (1995). To Be Professionally Effective, Be Politically Articulate. In J.M. Stein (Ed.) Classic Reading in Urban Planning. New York, St. Louis, San Francisco, Aukland, Bogota, McGraw-Hill.

Lambert, R. D. (1959). Factors in Bengali Regionalism. Far Eastern Survey, 28(4), 49-58.

Lewis, D. (2011). Bangladesh: Politics, Economics, and Civil Society. Cambridge, New York, Cambridge University Press.

Maria, S. I. M. I. (2006). Planning of Islamabad and Rawalpindi: What Went Wrong. ISoCaRP Congress. Istanbul, Turkey.

Maron, S. (1955). The Problem of East Pakistan. Pacific Affairs, 28(2), 132-144.

Mascarenhas, A. (1971). The Rape of Bangladesh. Delhi, Vikas.

MacFarlane, T., Minoprio, L. \& Spencely, T. (1959). Master Plan of Dhaka. Dhaka.

Meller, H. (1990). Patrick Geddes: Social Evolutionist and City Planner. London, Routledge.

Njoh, A. J. (2007). Planning Power: Town Planning and Social Control in Colonial Africa. London, UCL Press.

Post, J. (1996). The Politics of Urban Planning in the Sudan. Habitat International, 20(1), 121-137.

Qureshi, S. M. M. (1972-73). Pakistani Nationalism Reconsidered. Pacific Affairs, 45(4), 556-572.

Rabinovitz, F. F. (1967). Politics, Personality and Planning. Public Administration Review, 27(1), 18-24. 
Ray, A. B. (1977). Communal Attitudes to British Policy: The Case of the Partition of Bengal 1905. Social Scientist, 6(5), 34-46.

Ross, J. P. (1974). Theoretical Problems of Democratic Planning. Acta Sociologica, 17, 217-235.

Rydin, Y. (2011). The Purpose of Planning. Portland, Policy Press.

Schendel, W. V. (2009). A History of Bangladesh. Cambridge, UK: Cambridge University Press.

Schuman, H. (1972). A Note on the Rapid Rise of Mass Bengali Nationalism in East Pakistan. American Journal of Sociology, 78(2), 290-298.

SENES Consultants Limited, T. C. I. L. (2007). Dhaka Metropolitan Development Plan Strategic Environmental Assessment. Dhaka, The World Bank Washington, D. C. http://siteresources.worldbank.org/INTRANETENVIRONMENT/Resources/2443511222272730742/Final-DhakaSEA-11_Sep_2007.pdf

Thompson, H. R. (2007). Bangladesh. Language and National Identity in Asia. A. Simpson. Oxford New York, Oxford University Press.

Uddin, S. M. (2006). Constructing Bangladesh: Religion, Ethnicity, and Language in an Islamic Nation. Chapel Hill, University of North Carolina Press.

Vasu, M. L. (1979). Politics and Planning. Chapel Hill, the University of North Carolina Press.

Zaman, Q. M. \& Mahtab-Uz, S. S. Y. L. (2000). City Expansion Policy versus Compact City Demand: The Case of Dhaka. In R. M. Jenks (Ed.) Compact Cities. London and New York. 